\title{
US offers possible compromise at start of climate treaty talks
}

[KYOTO \& LONDON] The first day of the United Nations conference on climate change, which opened in Kyoto, Japan, this week, saw a significant policy shift by the United States that could pave the way for an eventual agreement on targets to reduce emissions of the manmade greenhouse gases that can cause global warming.

US officials announced on Monday (1 December) that they are willing to consider an agreement that contains different greenhouse gas reduction targets for different countries, rather than a flat-rate target for all developed countries.

Until now, most developed countries have supported a flat-rate target even though sharp differences remain on what that target should be. Australia, Canada and New Zealand are proposing some of the weakest targets. Most developing states support a 15 per cent reduction in emissions from 1990 levels by 2010, as proposed by the European Union (EU). The United States, meanwhile, has proposed merely bringing emissions back to 1990 levels before 2012 .

But Melinda Kimble, a state department official and a member of the US negotiating team at Kyoto, said on Monday that the United States is now willing to consider what is known as 'differentiation', "particularly if it would help resolve our remaining differences on the appropriate target level".

Further details are likely to emerge before US Vice-President Al Gore attends the conference next week. Gore confirmed his attendance only on Monday - but also said that the United States would be prepared to walk away from what it considered a bad treaty.

The 10-day conference is being attended by 10,000 participants comprising country representatives, nongovernmental organiza-

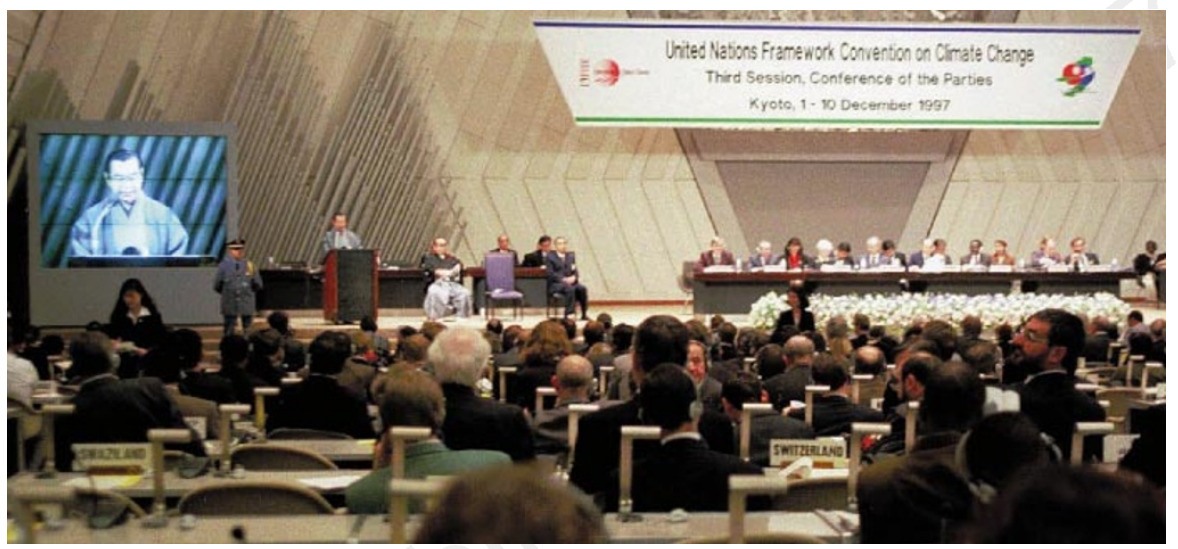

First words: Kyoto governor Teiichi Aramaki addresses the opening session of the climate meeting.

tions and the media. This week's talks between government officials are designed to lay the ground for the arrival of ministers next Monday ( 8 December) for three days of negotiations. The deadline for agreement is midnight on 10 December.

As the meeting opened, significant obstacles to an agreement remained. These included whether countries should be allowed to trade in emissions credits, the question of developing country participation, and even the definition of what constitutes 'anthropogenic' emissions of greenhouse gases.

Europe and developing countries remain opposed to US proposals to let countries achieve their targets via a greenhouse gas trading regime. Developing countries want the current pilot phase to continue, and, although Europe is not opposed in principle to greenhouse trading, it wants the United States to raise its overall reduction target first.

But US support for differentiation does provide a way of resolving another contentious issue: its insistence that voluntary

\section{Transgenic patents a step closer in Europe}

[MUNICH] The 'internal market' ministers of the member states of the European Union last week approved the latest draft of the European Commission's directive on the legal protection of biotechnological inventions, which allows the patenting of human genes as well as transgenic plants and animals.

The controversial directive has already been approved by the European Parliament in its first reading last July, following revisions to an earlier draft rejected two years ago (see Nature 388, 314; 1997). A text formally approved by the Council of Ministers is likely to be submitted to the parliament early next year. Assuming — as most commentators do - a reasonably trouble-free ride through its second parliamentary reading, the directive is likely to be adopted by the end of next summer.

The council's approval has dismayed environmentalist and other anti-patenting pressure groups, which continue to oppose the directive on moral grounds. But it has lifted spirits in the European Patent Office, where work on patent applications for biotechnological inventions has halted because of uncertainty over whether its own rules allow patents on life.
Alison Abbott targets be adopted by certain large developing states. Developing countries are exempt from reducing their greenhouse emissions at this stage under the terms of the UN climate convention, and want things to stay that way.

The United States has made clear that it will not sign an agreement at Kyoto unless larger developing countries such as India and China take steps to address their own emissions. According to Kimble, however: "Targets appropriate for developing countries need not take the same form as those under consideration for Annex 1 [developed] countries. They could take the form of emissions growth targets."

The United States used the opening day of the conference to step up its war of words with Europe. Kimble said: "The EU has not explained why it should not take on a more ambitious target in light of its unique economic advantage." This refers to the fact that EU member states such as Germany and the United Kingdom have achieved low emissions as the result of the closure of economically inefficient industries.

Europe is opposed to most of the US conditions for an agreement to limit emissions. Because of this it has enjoyed support from developing countries and plaudits from environmentalists. This has made US officials uncomfortable, and they used the first day of the conference to expose inconsistencies in the EU's proposal to limit emissions.

US support for differentiated targets puts the EU in an embarrassing position. Member states are opposed to differentiated targets. But their flat-rate target is the result of differentiated responsibilities between the 15 states. Some will reduce their emissions. Others, such as France, will stabilize. Poorer countries, such as Portugal and Greece, will be allowed to increase emissions to a certain level.

AsakoSaegusa\& Ehsan Masood 